\title{
Efektywna metoda identyfikacji zanieczyszczeń ropopochodnych (TPH) i wielopierścieniowych węglowodorów aromatycznych (WWA) w glebach
}

\begin{abstract}
W artykule przedstawiono metodykę oznaczania substancji ropopochodnych (TPH i WWA) w glebach. Opisano sposoby izolacji TPH i WWA z gleb za pomocą technik ekstrakcji rozpuszczalnikowej. Zanieczyszczenia ropopochodne TPH z matrycy glebowej wydzielono metodą ekstrakcji rozpuszczalnikowej, zmodyfikowaną poprzez zastosowanie ultradźwięków. Natomiast WWA wydzielono metodą ekstrakcji Soxhleta. Wykazano, że najwyższą efektywność ekstrakcji analitów z matrycy glebowej uzyskano przy zastosowaniu dichlorometanu (dla TPH) oraz eteru naftowego (dla WWA). Oczyszczenie/ rozdział analitu wykonano metodą ekstrakcji do fazy stałej SPE w oparciu o zasadę chromatograficznej separacji selektywnej adsorpcji i selektywnej elucji. Do badań stosowano kolumienki z wypełnieniami: florisil (oczyszczenie analitu ze związków polarnych) oraz CN/SiOH (selektywne wydzielenie WWA). Wydzielone z gleby TPH i WWA oznaczono metodą chromatografii gazowej. Opracowana metodyka jest wiarygodna i może być rekomendowana do stosowania podczas prac związanych z monitoringiem składu gleb potencjalnie skażonych substancjami ropopochodnymi.
\end{abstract}

Słowa kluczowe: substancje ropopochodne, wielopierścieniowe węglowodory aromatyczne WWA, gleba.

\section{An effective method for the identification of total petroleum hydrocarbons (TPH) and polycyclic aromatic hydrocarbons (PAHs) in soils}

The article presents the methodology for the determination of petroleum substances (TPH and PAHs) in soils. Describes methods of isolating TPH and PAH from soils by solvent extraction techniques. TPH derived from the soil matrix was separated by solvent extraction, modified by ultrasound. While the PAHs were isolated by Soxhlet extraction. It has been shown that the highest efficiency of extraction of analytes from the soil matrix was obtained using dichloromethane (for TPH) and petroleum ether (for PAHs). The purification/separation of the analyte was made by SPE solid phase extraction based on the principle of chromatographic selective adsorption separation and selective elution. Columns packed with florisil (purification of the analyte from polar pollutants) and with $\mathrm{CN} / \mathrm{SiOH}$ (selective separation of PAHs) were used for the studies. TPH and PAHs separated from the soil were determined using gas chromatography. The developed methodology is reliable and can be recommended for use during monitoring of soil compositions which can be potentially hydrocarbon contaminated.

Key words: total petroleum hydrocarbons, polycyclic aromatic hydrocarbons, soil.

\section{Wprowadzenie}

Działalność człowieka od wieków powoduje zmiany w środowisku, zmniejsza jego zasoby, modyfikuje naturalne cechy i powoduje wprowadzanie do środowiska obcych, niewystępujących naturalnie substancji. Niejednokrotnie mamy do czynienia z przedostawaniem się nadmiernych ilości szkodliwych substancji do środowiska gruntowo-wodnego, co znacznie spowalnia lub całkowicie zatrzymuje na- turalne procesy oczyszczania. Zmiany te, początkowo niewielkie, w miarę rozwoju techniki i przemysłu coraz bardziej widoczne i dotkliwe, wymagają poszukiwania metod przywracania właściwości użytkowych zanieczyszczonym elementom biosfery.

Górnicza eksploatacja, transport ropy oraz dystrybucja ropopochodnych produktów bywają przyczyną punktowego 
i obszarowego zanieczyszczenia ziemi. Źródłem antropogenicznej emisji zanieczyszczeń organicznych do środowiska naturalnego mogą być również procesy związane z niecałkowitym spalaniem paliw lub pirolizą.

W Polsce, jednym z krajów posiadających największe zasoby węgla w Europie, wszelkie technologie mające na celu pełniejsze wykorzystanie potencjału tego surowca spotykają się z dużym zainteresowaniem. Należy jednak zauważyć, że wytwarzanie gazu na drodze suchej destylacji węgla, będące synonimem wielkiego postępu cywilizacyjnego na przełomie XIX i XX wieku, wiąże się z otrzymywaniem smoły podestylacyjnej, zawierającej znaczne ilości wielopierścieniowych węglowodorów aromatycznych (WWA). Część tych substancji może przedostawać się do gruntu wskutek awarii w czasie produkcji czy też niewłaściwego składowania produktów odpadowych. Do chwili obecnej istnieją jeszcze zanieczyszczone tereny po instalacjach suchej destylacji węgla w zlikwidowanych gazowniach klasycznych.

Duże, przekraczające dopuszczalne normy, nagromadzenie w glebach węglowodorów ropopochodnych, a w szcze- gólności WWA, negatywnie wpływa na wegetację roślin oraz pozostałe organizmy żywe obecne w takim ekosystemie. Wielopierścieniowe węglowodory aromatyczne należą do trwałych zanieczyszczeń organicznych, charakteryzujących się w większości przypadków wysokimi właściwościami mutagennymi i kancerogennymi.

Substancje ropopochodne (TPH i WWA) stanowią jedno z głównych źródeł skażenia gleby, dlatego analiza tych zanieczyszczeń jest powszechnie prowadzona przez laboratoria. Aktualnie nie ma jednej całościowo znormalizowanej metodyki umożliwiającej identyfikację i ilościowe oznaczania wszystkich rodzajów zanieczyszczeń ropopochodnych w glebie. Przegląd prac opublikowanych na przełomie ostatnich lat wykazuje dużą rozbieżność w metodyce ich oznaczania $[1,3,4,6,7,9-20]$. Usystematyzowanie metodyki badań w zakresie analityki WWA i TPH umożliwi zaprezentowanie wiarygodnej metody ich oznaczania.

Znajomość składu substancji ropopochodnych zanieczyszczających gleby jest podstawą prowadzenia prac zmierzających do ich usunięcia ze skażonego środowiska.

\section{Materiał i metodyka badawcza}

Różnorodność produktów ropopochodnych, które mogą być źródłem skażenia, skomplikowany skład i zróżnicowane właściwości powodują trudności analityczne. Analiza zanieczyszczeń ropopochodnych $w$ glebie jest więc skomplikowaną procedurą składającą się z następujących etapów:

- pobór i wstępne przygotowanie próbek do analizy,

- izolacja i/lub wzbogacanie analitów przed etapem oznaczeń końcowych,

- identyfikacja i ilościowe oznaczenie analitów.

Materiał badawczy stanowiła gleba zanieczyszczona substancjami ropopochodnymi (TPH i WWA). Glebę tę doprowadzono do stanu powietrznie suchego poprzez kondycjonowanie w warunkach otoczenia w ciągu 7 dni. Powietrznie suchą glebę rozdrobniono i przesiano przez sito o wielkości oczek $1 \mathrm{~mm}$. Tak przygotowaną glebę poddano anali- zie pod kątem oznaczenia zawartości substancji ropopochodnych (TPH oraz WWA).

Izolację oznaczanych analitów z matrycy glebowej wykonano metodą ekstrakcji rozpuszczalnikowej poprzez:

- wydzielenie TPH metodą rozpuszczalnikową wspomaganą sonifikacją (częstotliwość ultradźwięków: $30 \mathrm{kHz}$, temperatura: $40^{\circ} \mathrm{C}$, czas: $30 \mathrm{~min}$ ), w celu zwiększenia stopnia odzysku analitu,

- wydzielenie WWA metodą ekstrakcji ciągłej Soxhleta,

- oczyszczenie/rozdział analitu metodą ekstrakcji do fazy stałej (SPE Solid Phase Extraction) w systemie próżniowym BAKER SPE - zastosowanie sekwencji rozpuszczalników organicznych i kolumienek SPE z wypełnieniami: florisil (oczyszczenie analitu ze związków polarnych) oraz $\mathrm{CN} / \mathrm{SiOH}$ (selektywne wydzielenie WWA),

- oznaczenie analitu metodą chromatografii gazowej.

\section{Aparatura badawcza}

Ekstrakcję TPH z gleby przeprowadzono metodą rozpuszczalnikową z wykorzystaniem wanny ultradźwiękowej SONOSWISS SW6H. Natomiast wydzielenie WWA wykonano w aparacie Soxhleta.

Rozdział/oczyszczanie TPH i WWA na kolumienkach SPE prowadzono z wykorzystaniem systemu próżniowego BAKER SPE (fotografia 1). Analizę zanieczyszczeń ropopochodnych w badanej glebie, obejmującą identyfikację oraz ilo- ściowe oznaczenie n-alkanów (n- $\left.\mathrm{C}_{6}-\mathrm{n}-\mathrm{C}_{44}\right)$, węglowodorów z grupy izoprenoidów (Pr i F), sumarycznej zawartości zanieczyszczeń ropopochodnych (TPH) oraz biomarkera $\mathrm{C}_{30} 17 \alpha(\mathrm{H})$, $21 \beta(\mathrm{H})$-hopanu, wykonano na chromatografie Clarus $500 \mathrm{GC}$ firmy Perkin Elmer, wyposażonym w kolumnę kapilarną Quadrex $007-1(30 \mathrm{~m} \times 0,53 \mathrm{~mm})$ firmy Restek, przy przepływie $20 \mathrm{ml} / \mathrm{min}$ helu jako gazu nośnego oraz przy zastosowaniu temperatury pieca: $30^{\circ} \mathrm{C}$ - przebieg izotermiczny $2 \mathrm{~min}, 30 \div 105^{\circ} \mathrm{C}-$ 


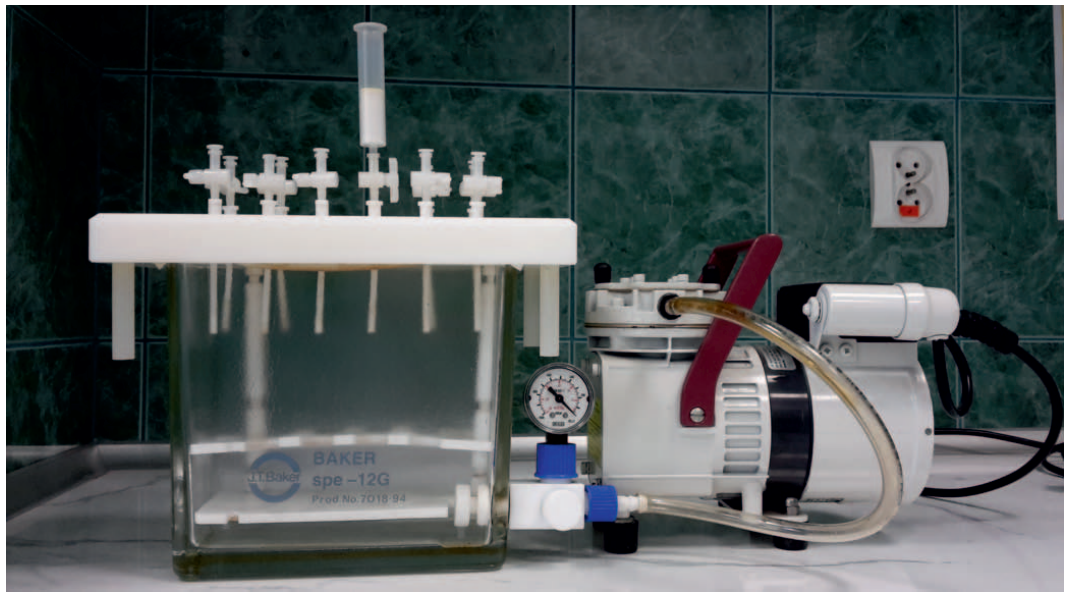

Fot. 1. System próżniowy BAKER SPE do przygotowania próbek Z wykorzystaniem kolumienek SPE

przyrost temperatury $10^{\circ} \mathrm{C} / \mathrm{min}, 105 \div 285^{\circ} \mathrm{C}$ - przyrost temperatury $5^{\circ} \mathrm{C} / \mathrm{min}, 285^{\circ} \mathrm{C}$ - przebieg izotermiczny $5 \mathrm{~min}$.

Dla biomarkera $\mathrm{C}_{30} 17 \alpha(\mathrm{H}), 21 \beta(\mathrm{H})$-hopanu zmodyfikowano program temperaturowy: $30^{\circ} \mathrm{C}$ - przebieg izotermiczny $2 \mathrm{~min}, 30 \div 105^{\circ} \mathrm{C}$ - przyrost temperatury $10^{\circ} \mathrm{C} / \mathrm{min}$, $105 \div 320^{\circ} \mathrm{C}$ - przyrost temperatury $6^{\circ} \mathrm{C} / \mathrm{min}, 320^{\circ} \mathrm{C}$ - przebieg izotermiczny $15 \mathrm{~min}$.

Do ilościowego oznaczania sumarycznej zawartości TPH zastosowano zestaw standardów kalibracyjnych firmy Tusnovics Instruments, zaś do ilościowego oznaczania poszczególnych n-alkanów wchodzących w skład zanieczyszczeń ropopochodnych wykorzystano certyfikowane wzorce firm Supelco i Restek (mieszaniny wzorcowe: nr D 2807 węglowodorów n-parafinowych: $n-\mathrm{C}_{6}-\mathrm{n}-\mathrm{C}_{44}$ oraz nr A 029668: Fuel Oil Degradation Mix n- $\mathrm{C}_{17}$, pristan, $n-\mathrm{C}_{18}$, fitan). Jako biomarker zastosowano certyfikowany wzorzec $\mathrm{C}_{30} 17 \alpha(\mathrm{H})$, 21ß(H)-hopan firmy Supelco.
Certyfikowany wzorzec (BAM K010) firmy Tusnovics Instruments posłużył do sporządzenia krzywej kalibracyjnej TPH w zakresie stężeń $50 \div 3000 \mathrm{mg} / \mathrm{kg}$ s.m., umożliwiającej ilościowe oznaczenie sumarycznej zawartości zanieczyszczeń ropopochodnych (TPH).

Analizę chromatograficzną obejmującą oznaczenie 16 WWA oraz WWAs i biomarkeru $\mathrm{C}_{30} 17 \alpha(\mathrm{H}), 21 \beta(\mathrm{H})$-hopanu, stosowanego do oceny kinetyki biodegradacji poszczególnych zidentyfikowanych WWA, wykonano na chromatografie gazowym $\mathrm{z}$ detektorem płomieniowo-jonizacyjnym (GC/FID) Clarus 500 firmy Perkin Elmer, wyposażonym w kolumnę kapilarną RTX-440 (50 $\mathrm{m} \times 0,25 \mathrm{~mm})$ firmy Restek, przy programie temperaturowym: $40^{\circ} \mathrm{C}-$ przebieg izotermiczny, $40 \div 240^{\circ} \mathrm{C}$ - przyrost temperatury $30^{\circ} \mathrm{C} / \mathrm{min}$, $240 \div 320^{\circ} \mathrm{C}$ - przyrost temperatury $8^{\circ} \mathrm{C} / \mathrm{min}, 320^{\circ} \mathrm{C}$ - przebieg izotermiczny $10 \mathrm{~min}$.

Do identyfikacji 16 WWA oraz ich ilościowego oznaczenia zastosowano zestaw standardów kalibracyjnych firmy Restek. Posłużyły one do sporządzenia krzywej kalibracyjnej (w programie TurboChrom 6.1), umożliwiającej ilościowe oznaczenie poszczególnych WWA. Jako wzorzec biomarkera zastosowano certyfikowany biomarker $-\mathrm{C}_{30} 17 \alpha(\mathrm{H})$, 21ß(H)-hopan firmy Supelco.

W celu przetestowania przedstawionej metodyki chromatograficznego oznaczania WWA z wykorzystaniem chromatografu GC Clarus 500 wykonano analizę certyfikowanej mieszaniny wzorcowej (wielopierścieniowe węglowodory aromatyczne w glebie) firmy BAM-ERM-CC013, która potwierdziła poprawność doboru opracowanej metodyki.

\section{Izolacja ropopochodnych składników TPH z gleby}

Zastosowanie metodyki chromatograficznego oznaczania substancji ropopochodnych w glebach wymaga przeprowadzenia oznaczanych składników z gleby do innej matrycy. Najczęściej izolację i wzbogacanie analitów wykonuje się metodami ekstrakcyjnymi. Stosowane są również modyfikacje tych metod, polegające na wprowadzeniu nowych technik w celu: skrócenia czasu ekstrakcji, zmniejszenia ilości rozpuszczalników, wydzielenia różnych grup analitów. Należą do nich: ekstrakcja sekwencyjna - wielokrotna ekstrakcja różnymi rozpuszczalnikami specyficznymi do danej frakcji, sonifikacja - wspomaganie ekstrakcji ultradźwiękami (U.S. EPA Method 3550C, ultrasonic extraction), wspomaganie ekstrakcji promieniowaniem mikrofalowym (U.S. EPA Method 3546 microwave extraction), ekstrakcja płynem w stanie nadkrytycznym oraz ekstrakcja przyspie- szona w podwyższonej temperaturze i pod zwiększonym ciśnieniem $\left(T=120^{\circ} \mathrm{C}, P=14 \mathrm{MPa}\right)$.

Wydzielony metodą ekstrakcyjną analit wymaga oczyszczenia $\mathrm{z}$ interferentów na drodze ekstrakcji na złożu sorpcyjnym SPE.

Podczas ekstrakcji do fazy stałej skład próbki, faza stacjonarna i faza ruchoma muszą zostać tak dobrane, aby - znając rozpuszczalność i oddziaływania grup funkcyjnych między wymienionymi wyżej elementami układu - zapewnić zatrzymanie bądź wymycie analitu z kolumienki. Efekt ten można osiągnąć poprzez $[2,5]$ :

- $\quad$ selektywne wymywanie - kolumienkę (po naniesieniu próbki) przemywa się taką objętością rozpuszczalnika, aby usunąć zanieczyszczenia, a na kolumnie zostawić anality, - selektywną elucję - wymycie analitów rozpuszczalnikiem, 
który nie eluuje silnie zatrzymanych na sorbencie interferentów.

Dobór sorbentów i rozpuszczalników do ekstrakcji cieczciało stałe dokonywany jest na podstawie ich polarności, jonizowalności i rozpuszczalności w wodzie lub rozpuszczalnikach organicznych (rysunek 1) [2].

Opierając się na danych literaturowych [4, 6, 10-12, 17, 20], przebadano rozpuszczalniki: tetrachlorek węgla, dichlorometan, heksan + chlorek metylenu + chloroform w stosunku 1:1:1, heksan + aceton w stosunku 1:1, heksan + dichlorometan w stosunku 1:1 oraz chlorometan, pod kątem efektywności odzysku TPH z gleby.

Jako optymalny rozpuszczalnik wytypowano dichlorometan, dla którego osiągnięto stopień odzysku analitu w ilości $85,7 \%$. Zastosowanie w procesie ekstrakcji sonifikacji spowodowało zwiększenie stopnia odzysku do 95,9\%. Stopień odzysku analitów określano za pomocą standardu zastępczego, którym był o-terfenyl.

Izolację analitów prowadzono metodą rozpuszczalnikową zmodyfikowaną poprzez zastosowanie ultradźwięków. Dla uzyskania wysokiego odzysku analitów z matrycy glebowej ekstrakcję powtarzano trzykrotnie małymi porcjami rozpuszczalnika. W okresie trwania procesu sonifikacji nie stwierdzono artefaktów.

Oczyszczanie analitów z substancji polarnych przeprowadzono przy zastosowaniu kolumienek SPE wypełnionych złożem Florisil [11]. Przed użyciem kolumienki złoże kondycjonowano poprzez przemycie $2 \mathrm{ml}$ metanolu. Nie dopuszczając do wyschnięcia złoża, naniesiono na nie wcześniej wyekstrahowane substancje ropopochodne TPH. Analit eluowano dichlorometanem, po czym zatężono i wykonano analizę chromatograficzną.

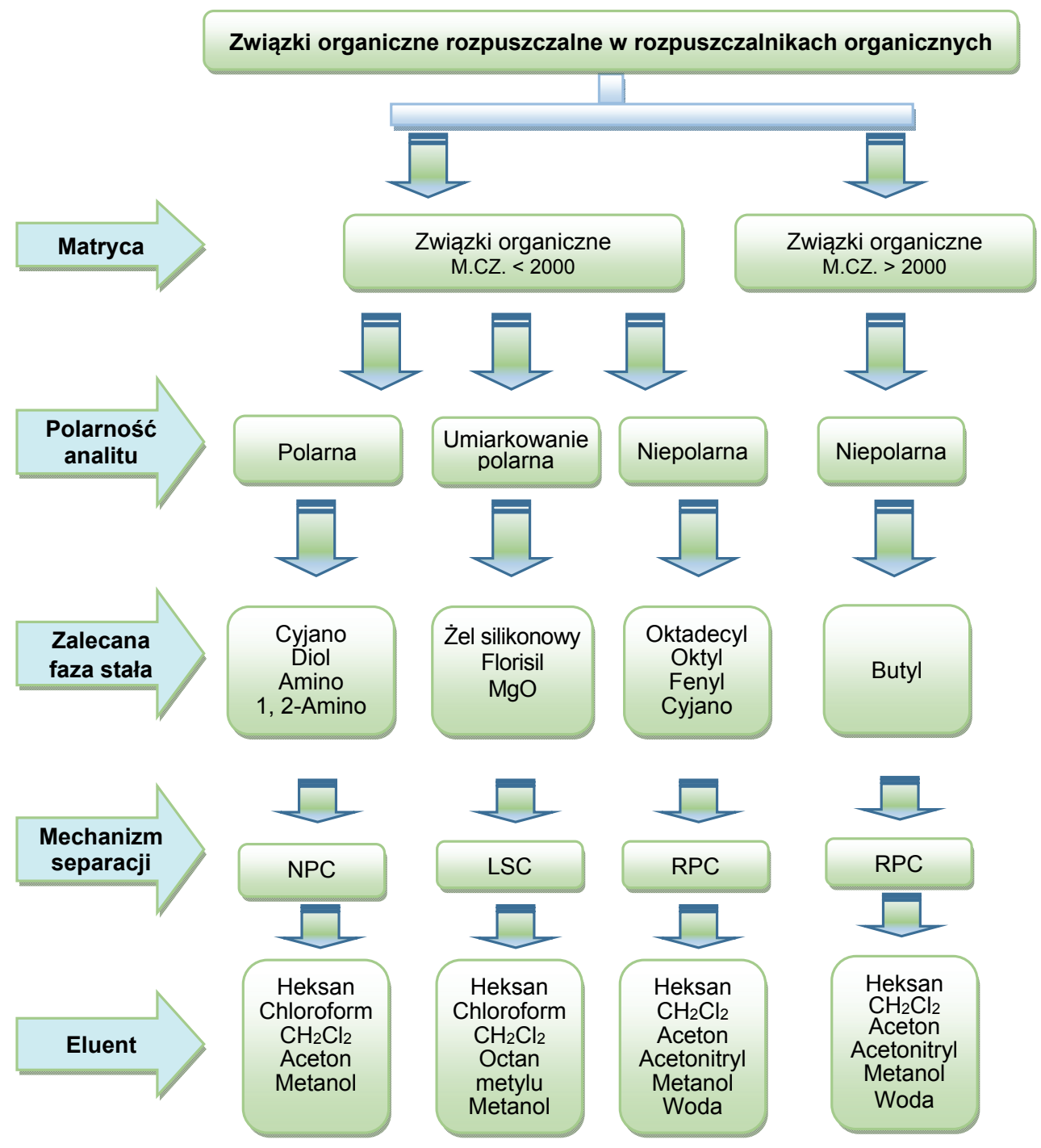

Rys. 1. Schemat doboru sorbentów i rozpuszczalników do ekstrakcji substancji organicznych metodą ciecz-ciało stałe [2]

Mechanizmy separacji:

NPC - chromatografia w normalnym układzie faz,

LSC - chromatografia adsorpcyjna,

RPC - chromatografia w odwróconym układzie faz. 


\section{Izolacja WWA z gleby}

W celu przetestowania przedstawionej metodyki chromatograficznego oznaczania WWA z wykorzystaniem chromatografu GC Clarus 500 wykonano analizę certyfikowanej mieszaniny wzorcowej (wielopierścieniowe węglowodory aromatyczne w glebie firmy BAM-ERM-CC013), która potwierdziła poprawność doboru opracowanej metodyki. Uzyskane wyniki analizy chromatograficznej i obliczona niepewność ich oznaczeń są zgodne z certyfikatem testowanej mieszaniny wzorcowej.

Warunkiem koniecznym do prawidłowego przeprowadzenia procesu analizy WWA jest ich wyizolowanie $\mathrm{z}$ badanej próbki gleby. W tym celu dokonano przeglądu poszczególnych procedur ekstrakcyjnych w renomowanych czasopismach opisujących procesy izolacji WWA z gleby.

Najczęściej izolację prowadzi się metodą ekstrakcyjną, stosując rozpuszczalniki organiczne lub ich mieszaniny (np. heksan i aceton w odpowiednio dobranym stosun$\mathrm{ku}$ ), wspomaganą poprzez zastosowanie podwyższonego ciśnienia i temperatury czy ultradźwięków lub promieniowania mikrofalowego.

Wilcke [18] jako optymalny rozpuszczalnik do ekstrakcji WWA z gleby $\left(T=120^{\circ} \mathrm{C}, P=14 \mathrm{MPa}, t=8 \mathrm{~min}\right)$ zastosował mieszaninę heksanu i acetonu w stosunku 2:1.

Wydzielenia z ekstraktu frakcji aromatycznej prowadzono metodą SPE na złożu $\mathrm{Al}_{2} \mathrm{O}_{3} / \mathrm{SiO}_{2} \mathrm{z}$ wykorzystaniem rozpuszczalników: $15 \mathrm{ml}$ heksan, $5 \mathrm{ml}$ heksan-dichlorometan 9:1, $20 \mathrm{ml}$ heksan-dichlorometan 4:1.

Jako rozpuszczalniki do rozdziału związków aromatycznych na złożach $\mathrm{Al}_{2} \mathrm{O}_{3} / \mathrm{SiO}_{2}$ kolumienek stosowane są również mieszaniny heksanu i acetonu w stosunkach 1:1 [13,19], 4:1 [2] oraz 9:1 [1], w ekstrakcji przyspieszonej $\left(T=110 \div 120^{\circ} \mathrm{C}, P=14 \mathrm{MPa}\right.$, $t=6 \div 8 \mathrm{~min}$ ).

Do innych rekomendowanych rozpuszczalników ekstrakcyjnych należą: toluen [9], chlorek metylu [7, 14], heksan i dichlorometan w stosunku 1:1 [6].

Opierając się na doniesieniach literaturowych i własnych doświadczeniach [16], opracowano metodykę izolacji frakcji aromatycznej WWA (metoda A), która obejmowała:

- izolację analitów (WWA) poprzez zastosowanie ciągłej ekstrakcji (według Soxhleta) za pomoca eteru naftowego (frakcja $40 \div 60^{\circ} \mathrm{C}$ ) i zatężenia próbki do objętości $5 \mathrm{ml}$,

- wydzielenie frakcji WWA przy zastosowaniu dwufazowych kolumienek Barkarbord SPE PAH Soil zawierających fazy: $500 \mathrm{mg}$ cyjano/100 mg Silica Gel,

- elucję z zastosowaniem mieszaniny rozpuszczalników $3 \times 3 \mathrm{ml}$ acetonu i toluenu w stosunku 3:1,

- oczyszczenie analitu z wykorzystaniem kolumienki SPE ze złożem Florisil firmy Supelco.

Efektywność stosowania opracowanej metodyki izolacji WWA z gleby (metoda A) określono poprzez porównanie jej z innymi metodami proponowanymi w literaturze (metody B i C). Wyniki analiz chromatograficznych wydzielonych analitów przedstawiono w tablicy 1 i na rysunku 2 . Ponadto na rysunku 3 zobrazowano chromatogram rozdziału zidentyfikowanych WWA oraz biomarkera C30 17 $\alpha(\mathrm{H})$, 21ß(H)-hopanu z badanej próbki gleby.

Metoda A - opracowana metodyka z zastosowaniem jako rozpuszczalnika eteru naftowego.

Metoda B - zastosowanie jako rozpuszczalnika mieszaniny: heksan-aceton w stosunku 2:1 i wydzielenie frakcji aromatycznej w kolumience ze złożami $\mathrm{Al}_{2} \mathrm{O}_{3} / \mathrm{SiO}_{2}$.

Tablica 1. Porównanie zawartości zidentyfikowanych WWA przy zastosowaniu różnych układów ekstrahentów i sposobu izolacji frakcji aromatycznej z gleby

\begin{tabular}{|l|c|c|c|}
\hline \multirow{2}{*}{ Składnik WWA } & $\begin{array}{c}\text { Zawartość WWA } \\
{[\mathrm{mg} / \mathrm{kg} \text { s.m. }}\end{array}$ & $\begin{array}{c}\text { Zawartość WWA } \\
{[\mathrm{mg} / \mathrm{kg} \mathrm{s.m.}]}\end{array}$ & $\begin{array}{c}\text { Zawartość WWA } \\
{[\mathrm{mg} / \mathrm{kg} \text { s.m. }}\end{array}$ \\
\cline { 2 - 4 } & metoda A & metoda B & metoda C \\
\hline Naftalen (N) & 10,13 & 11,47 & 8,61 \\
\hline Acenaftalen (Acl) & 15,97 & 17,86 & 15,99 \\
\hline Acenaften (Ac) & 21,37 & 20,14 & 19,39 \\
\hline Fluoren (Fluo) & 11,57 & 10,47 & 11,45 \\
\hline Fenantren (Fen) & 86,34 & 75,32 & 58,75 \\
\hline Antracen (A) & 89,33 & 101,66 & 87,35 \\
\hline Fluoranten (F) & 155,33 & 173,49 & 133,36 \\
\hline Piren (Pir) & 146,11 & 167,67 & 123,78 \\
\hline Benzo(a)antracen (BaA) & 138,02 & 143,13 & 107,22 \\
\hline Chryzen (CH) & 108,58 & 112,67 & 96,15 \\
\hline Benzo(b)fluoranten (BbF) & 200,67 & 167,65 & 135,52 \\
\hline Benzo(k)fluoranten (BkF) & 77,46 & 68,65 & 59,73 \\
\hline Benzo(a)piren (BaP) & 107,50 & 91,76 & 68,65 \\
\hline Dibenzo(a,h)antracen (DaA) & 81,09 & 69,75 & 47,51 \\
\hline Indeno(1,2,3,cd)piren (IndP) & 19,97 & 11,26 & 9,02 \\
\hline Benzo(g,h,i)perylen (BghiP) & 75,32 & 53,25 & 33,33 \\
\hline Suma (WWAs) & 1711,47 & 1581,26 & 1398,10 \\
\hline Stopień odzysku & $93,1 \%$ & $86,0 \%$ & $76,1 \%$ \\
\hline
\end{tabular}


Metoda C - zastosowanie jako rozpuszczalnika mieszaniny: heksan-dichlorometan $\mathrm{w}$ stosunku 1:1 i oczyszczenie na kolumience wypełnionej tlenkiem glinu.

W wyniku zastosowania różnych układów rozpuszczalników i sposobów izolacji WWA uzyskano nieznacznie różniące się wyniki (tablica 1 , rysunek 2). Porównując izolację WWA za pomocą metod A i B, stwierdzić należy, że izolacja frakcji organicznej uzyskana w wyniku zastosowania metody B była bardziej skuteczna w przypadku: naftalenu $(\mathrm{N})$ o $13,2 \%$, acenaftalenu (Acl) o 11,8\%, antracenu (A) o $13,8 \%$, fluorantenu (Fen) o $11,7 \%$, pirenu (Pir) o 14,8\%, benzo(a)antracenu (BaA) o $3,7 \%$, chryzenu $(\mathrm{CH})$ o 3,8\%. Natomiast w przypadku węglowodorów o wyższej liczbie pierścieni w cząsteczce wyizolowano znacznie niższe ich ilości.

W przypadku zastosowania do ekstrakcji układu rozpuszczalników heksan-dichlorometan w stosunku 1:1 (metoda C) wyizolowano znacznie niższe ilości poszczególnych WWA w porównaniu z metodami A i B.

Porównując wyniki analiz chromatograficznych wyizolowanych WWA, należy stwierdzić, że najwyższy stopień odzysku frakcji aromatycznej uzyskano dla metody A. W związku z powyższym została ona wytypowana jako optymalna do izolacji WWA z gleb.

W celu przetestowania opracowanej metodyki chromatograficznego oznaczania
WWA w glebie wykonano serię 10 analiz i obliczono względne odchylenie standardowe [RSD \%] dla poszczególnych zidentyfikowanych WWA. Wartości RSD procentowo kształtowały się na poziomie $6,68 \div 24,36 \%$, co świadczy o zadowalającej dokładności i precyzji opracowanej metodyki.

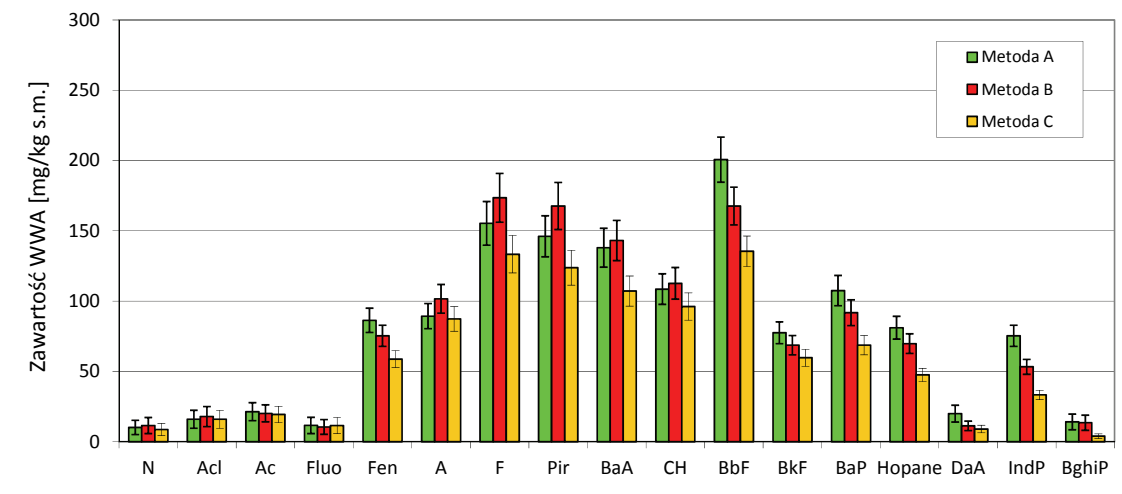

Rys. 2. Porównanie zawartości zidentyfikowanych WWA przy zastosowaniu różnych układów ekstrahentów i sposobu izolacji frakcji aromatycznej z gleby

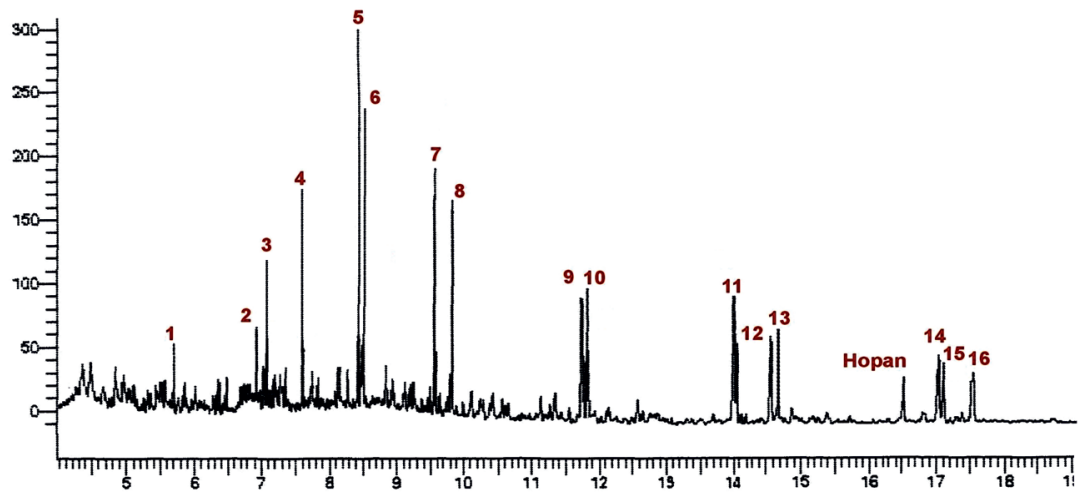

Rys. 3. Chromatogram rozdziału zidentyfikowanych wielopierścieniowych węglowodorów aromatycznych (16 WWA) oraz biomarkera C30 17 $\alpha(\mathrm{H})$, $21 \beta(\mathrm{H})$-hopanu z gleby

\section{Charakterystyka materiału badawczego}

Materiał badawczy stanowiła próbka gleby zanieczyszczonej substancjami ropopochodnymi. Ekstrakcję substancji ropopochodnych (TPH i WWA) z gleby przeprowadzono według wcześniej opracowanych metodyk badawczych. Następnie wykonano analizy chromatograficzne kolejno otrzymanych ekstraktów gleby pod kątem oznaczenia TPH i WWA. Wyniki analiz chromatograficznych przedstawiono w tablicach 2 i 3 .

Analiza chromatograficzna wykonana pod kątem oznaczania zanieczyszczeń ropopochodnych TPH wykazała, że ich sumaryczna zawartość w próbce gleby wynosiła 16092 mg/kg s.m. Procentowy udział zidentyfikowanych węglowodorów kształtował się następująco:

- węglowodory z grupy $n-\mathrm{C}_{10}-\mathrm{n}-\mathrm{C}_{13}-13,2 \%$,

- węglowodory z grupy $n-C_{14}-n-C_{16}-9,9 \%$,
- węglowodory z grupy $n-C_{17}-n-C_{19}-22,5 \%$,

- węglowodory z grupy $n-\mathrm{C}_{20}-\mathrm{n}-\mathrm{C}_{32}-17,6 \%$,

- izoprenoidy (Pr i F) - 2,3\%,

- niezidentyfikowane $-34,5 \%$.

Sumaryczna zawartość wielopierścieniowych węglowodorów aromatycznych WWAs w badanej próbce gleby wynosiła 3256,5 mg/kg s.m. (tablica 3).

Procentowy udział poszczególnych 16 zidentyfikowanych podczas analizy chromatograficznej WWA kształtował się na następującym poziomie: WWAs 2-pierścieniowe - 1,9\%, WWAs 3-pierścieniowe - 59,9\%, WWAs 4-pierścieniowe 28,7\%, WWAs 5-pierścieniowe-8,2\%, WWAs 6-pierścieniowe - 1,2\%.Wykonana analiza chromatograficzna zanieczyszczonej gleby wykazała wysoki stopień jej skażenia zarówno substancjami ropopochodnymi TPH, jak i wielopierścieniowymi 
Tablica 2. Zestawienie wyników analiz chromatograficznych zidentyfikowanych węglowodorów wchodzących w skład zanieczyszczeń (TPH) w próbce gleby

\begin{tabular}{|c|c|c|c|c|c|}
\hline $\begin{array}{l}\text { Oznaczany } \\
\text { składnik }\end{array}$ & $\begin{array}{c}\text { Zawartość } \\
{[\mathrm{mg} / \mathrm{kg} \text { s.m. }]}\end{array}$ & $\begin{array}{l}\text { Oznaczany } \\
\text { składnik }\end{array}$ & $\begin{array}{c}\text { Zawartość } \\
{[\mathrm{mg} / \mathrm{kg} \text { s.m. }]}\end{array}$ & $\begin{array}{l}\text { Oznaczany } \\
\text { składnik }\end{array}$ & $\begin{array}{c}\text { Zawartość } \\
{[\mathrm{mg} / \mathrm{kg} \mathrm{s.m.]}}\end{array}$ \\
\hline$n-C_{10}$ & 461,5 & $n-C_{17}$ & 2230,5 & $\mathrm{n}-\mathrm{C}_{24}$ & 707,6 \\
\hline $\mathrm{n}-\mathrm{C}_{11}$ & 230,7 & pristan $(\mathrm{Pr})$ & 246,1 & $n-C_{26}$ & 492,2 \\
\hline $\mathrm{n}-\mathrm{C}_{12}$ & 1153,7 & $\mathrm{n}-\mathrm{C}_{18}$ & 1015,2 & $\mathrm{n}-\mathrm{C}_{28}$ & 169,2 \\
\hline$n-C_{13}$ & 276,9 & fitan $(F)$ & 123,1 & $\mathrm{n}-\mathrm{C}_{30}$ & 153,8 \\
\hline $\mathrm{n}-\mathrm{C}_{14}$ & 384,6 & $\mathrm{n}-\mathrm{C}_{19}$ & 369,2 & hopan & 5,0 \\
\hline$n-C_{15}$ & 261,5 & $\mathrm{n}-\mathrm{C}_{20}$ & 646,1 & $\mathrm{n}-\mathrm{C}_{32}$ & 46,2 \\
\hline$n-C_{16}$ & 953,7 & $n-C_{22}$ & 615,3 & niezidentyfikowane & 5550,0 \\
\hline & & & & Suma (TPH): & 16092,0 \\
\hline
\end{tabular}

węglowodorami aromatycznymi. Wartości te znacznie przekraczają dopuszczalne standardy glebowe określone w polskim ustawodawstwie (Dz.U. 2016, poz. 1395).

Wnioskiem wynikającym z wykonanych badań jest niewątpliwie stwierdzenie, że teren, z którego pobrano próbę glebową należy poddać procesowi rekultywacji. Proces ten nie będzie łatwy z uwagi na dużą ilość WWA trudno ulegających biodegradacji, które wchodzą w skład zanieczyszczeń.

Opracowana metodyka oznaczania substancji ropopochodnych TPH i wielopierścieniowych węglowodorów aromatycznych $\mathrm{w}$ glebach, wykonywana $\mathrm{w}$ ramach prowadzenia monitoringu potencjalnie skażonych terenów, może być rekomendowana w przypadku podejmowania decyzji o skutecznych technologiach oczyszczania gruntów. Ponadto może
Tablica 3. Zestawienie wyników analiz chromatograficznych zidentyfikowanych wielopierścieniowych węglowodorów aromatycznych (WWA) w próbce gleby

\begin{tabular}{|c|c|c|c|}
\hline Oznaczany składnik & $\begin{array}{c}\text { Zawartość } \\
{[\mathrm{mg} / \mathrm{kg} \mathrm{s.m} .]}\end{array}$ & Oznaczany składnik & $\begin{array}{c}\text { Zawartość } \\
{[\mathrm{mg} / \mathrm{kg} \text { s.m. }}\end{array}$ \\
\hline Naftalen (N) & 51,5 & WWAs - 4-pierścieniowe & 766,8 \\
\hline Acenaftalen (Acl) & 56,2 & Benzo(b)fluoranten (BbF) & 84,3 \\
\hline Acenaften (Ac) & 149,9 & Benzo(k)fluoranten (BkF) & 51,5 \\
\hline Fluoren (Fluo) & 281,0 & Benzo(a)piren (BaP) & 56,2 \\
\hline Fenantren (Fen) & 749,3 & Hopan C30 17 $(\mathrm{H}), 21 \beta(\mathrm{H})$ & 5,0 \\
\hline Antracen (A) & 365,3 & Dibenzo(a,h)antracen (DaA) & 23,4 \\
\hline WWAs-3-pierścieniowe & 1601,7 & WWAs - 5-pierścieniowe & 220,4 \\
\hline Fluoranten (F) & 271,6 & Indeno(1,2,3,cd)piren (IndP) & 18,7 \\
\hline Piren (Pir) & 284,2 & Benzo(g,h,i)perylen (BghiP) & 14,1 \\
\hline Benzo(a)antracen (BaA) & 103,3 & WWAs - 6-pierścieniowe & 32,8 \\
\hline Chryzen (CH) & 107,7 & Suma (WWAs): & 3256,5 \\
\hline
\end{tabular}

być wykorzystywana do monitorowania postępu degradowania zanieczyszczeń węglowodorowych w gruncie podczas ich oczyszczania, na podstawie czego można ocenić efektywność zastosowanej technologii rekultywacji gruntów.

\section{Podsumowanie}

Proces oznaczania substancji ropopochodnych TPH i WWA w glebie składa się z etapów: poboru i wstępnego przygotowania próbek gleby (suszenie, rozdrabnianie), izolacji i/lub wzbogacania analitów przed etapem oznaczeń końcowych oraz identyfikacji i ilościowego oznaczenia analitów.

Opracowana metodyka izolacji TPH i WWA z matrycy glebowej wykonana metodą ekstrakcji rozpuszczalnikowej obejmowała:

- wydzielenie TPH metodą rozpuszczalnikową wspomaganą sonifikacją (częstotliwość ultradźwięków: $30 \mathrm{kHz}$, temperatura: $40^{\circ} \mathrm{C}$, czas: $30 \mathrm{~min}$ ), co powoduje zwiększenie stopnia odzysku analitu,
- wydzielenie WWA metodą ekstrakcji ciągłej Soxhleta,

- oczyszczenie/rozdział analitu metodą ekstrakcji do fazy stałej (SPE - Solid Phase Extraction) w systemie próżniowym BAKER SPE - zastosowanie sekwencji rozpuszczalników organicznych i kolumienek SPE z wypełnieniami: florisil (oczyszczenie analitu ze związków polarnych) oraz CN/SiOH (selektywne wydzielenie WWA),

- oznaczenie analitu metodą chromatografii gazowej.

Jest to metoda wiarygodna i może być rekomendowana do stosowania podczas prac związanych z monitoringiem składu gleb potencjalnie skażonych substancjami ropopochodnymi. 
Znajomość jakości i ilości zidentyfikowanych węglowodorów przyczyni się do podejmowania decyzji o strategicznych parametrach prowadzenia procesu rekultywacji grun- tów, w wyniku którego nastąpi obniżenie koncentracji zanieczyszczeń do bezpiecznego poziomu, zgodnego z obowiązującym ustawodawstwem.

Prosimy cytować jako: Nafta-Gaz 2017, nr 7, s. 488-495, DOI: 10.18668/NG.2017.07.06

Artykuł nadesłano do Redakcji 9.12.2016 r. Zatwierdzono do druku 14.04.2017 r.

Artykuł powstał na podstawie pracy statutowej pt.: Ocena składu zanieczyszczeń gleb skażonych TPH $i$ WWA pod katem opracowania technologii ich bioremediacji - praca INiG - PIB na zlecenie MNiSW; nr zlecenia: 0034/KE, nr archiwalny: DK-4100-0034/16.

\section{Literatura}

[1] Alexander R.R., Tang J., Alexander M.: Genotoxicity is unrelated to total concentration of priority carcinogenic polycyclic aromatic hydrocarbons in soils undergoing biological treatment. J. Environ. Qual. 2002, vol. 31, s. 150-154.

[2] Baker J.T., Witko S.: Wasi doświadczeni przewodnicy w czasie ekstrakcji ciecz - ciało stałe; http://www.witko.com.pl/ attach/9afda348f09dc6953ac56dc2c22add1b/przygotowanie_probek_SPE.pdf (dostęp: październik 2016).

[3] Bożym M., Poluszyńska J., Sławińska I., Dwojak J.: Oznaczanie wielopierścieniowych węlowodorów aromatycznych w stałych próbkach środowiskowych z wykorzystaniem chromatografi gazowej sprzężonej ze spektrometria mas GC-MS Prace Instytutu Szkła, Ceramiki, Materiałów Ogniotrwałych i Budowlanych 2009, tom 2, nr 4, s. 155-164.

[4] Chaîneau C.H., Yepremian C., Vidalie J.F., Ducreux J., Ballerini D.: Bioremediation of a crude oil-polluted soil: biodegradation, leaching and toxicity assessments. Water, Air and Soil Pollution 2003, vol. 144, s. 419-440.

[5] Czerwiński J.: Zastosowanie technik ekstrakcji do fazy stałej oraz bezpośredniego nastrzyku na kolumne chromatograficzna do oznaczania związów organicznych $w$ próbkach cieklych. Praca doktorska. Politechnika Gdańska 1996.

[6] Fismes J., Perrin-Ganier C., Empereuer-Bissonnet P., Morel J.L.: Soil-root transfer and translocation of polycyclic aromatic hydrocarbons by vegetables grown on industrial contaminated soils. J. Environ. Qual. 2002, vol. 31, s. 1649-1656.

[7] Huesemann H.M., Hausmann T.S., Fortman T.J.: Assessement of bioavailability limitations during slurry biodegradation of petroleum hydrocarbons in aged soils. Environ. Toxicology and Chemistry 2003, vol. 12, s. 2853-2860.

[8] Hutchinson S.L., Banks M.K., Schwab A.P.: Phytoremediation of Aged Petroleum Sluge. Effect of Inorganic Fertlizer. J. Environ. Qual. 2001, vol. 30, s. 395-403.

[9] Johnsen A.R., Winding A., Karlson U., Roslev P.: Linking of microorganisms to phenanthrene metabolism in soil by analysis of 13C-Labeled cell lipids. Applied Environm. Microbiol. 2002, vol. 68, s. 6106-6113.

[10] Katsivela E., Moore E.R.D., Kalogerakis N.: Biodegradation of aliphatic and aromatic hydrocarbons: Specificity among bacteria isolated from refinery waste sludge. Water, Air and Soil Pollution 2003, vol. 3, s. 103-115.

[11] Kluk D., Steliga T.: Ocena zmian toksyczności gleby skażonej niklem i substancjami ropopochodnymi $w$ procesach fitoremediacji. Nafta-Gaz 2016, nr 4, s. 230-241; DOI: 10.18668/ NG.2016.04.02.

[12] Li H., Zhang Y., Zhang C.G., Chen G.X.: Effect of petroleumcontaining wastewater irrigation on bacterial diversities and enzymatic activities in a Paddy soil irrigation area. J. Environ. Qual. 2005, vol. 34, s. 1073-1080.

[13] Majkowska E., Mucha P., Niemczyk B., Trela D.: Oznaczenie zawartości antracenu $w$ próbkach gleby pobranej z $O j$ cowskiego Parku Narodowego. Analit 2016, nr 1, s. 15-31.

[14] Sharma V.K., Hicks S.D., Rivera W., Vazquez F.G.: Characterization and degradation of petroleum hydrocarbons following an oil spill into a coastal environment of south Texas, USA. Water, Air and Soil Pollution 2002, vol. 134, s. 111-127.

[15] Smułek W., Kaczorek E.: Wykorzystanie surfaktantów naturalnych $w$ biodegradacji oleju napędowego. Nafta-Gaz 2015, nr 2, s. 104-109.

[16] Steliga T.: Bioremediacja odpadów wiertniczych zanieczyszczonych substancjami ropopochodnymi ze starych dolów urobkowych. Prace INiG 2009, nr 163, s. 39-66.

[17] Steliga T., Kapusta P., Jakubowicz P.: Biodegradacja ex situ gruntu z klasycznych gazowni skażonego weglowodorami ropopochodnymi. Zeszyty Naukowe AGH: Wiertnictwo Nafta Gaz 2007, tom 24(1), s. 475-486.

[18] Wilcke W., Krauss M., Lilienfein J., Amelung W.: Polycyclic aromatic hydrocarbon storage in a tipical Cerrado of the Brazilian Savanna. J. Environ. Qual. 2004, vol. 33, s. 946-955.

[19] Xu R., Lau N.L.A., Ng K.L., Obbard J.P.: Application of a slow-release fertilizer for oil bioremediation in beach sediment. J. Environ. Qual. 2004, vol. 33, s. 1210-1216.

[20] Xu R., Obbard J.P.: Biodegradation of polycyclic aromatic hydrocarbons in oil-contaminated beach sediments treated with nutrient amendments. J. Environ. Qual. 2004, vol. 33, s. 861-867.

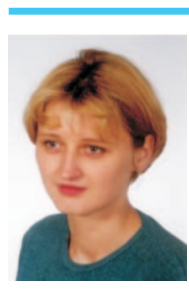

Mgr inż. Dorota KLUK

Starszy specjalista badawczo-techniczny w Zakładzie Technologii Eksploatacji Płynów Złożowych. Instytut Nafty i Gazu - Państwowy Instytut Badawczy ul. Lubicz $25 \mathrm{~A}$

31-503 Kraków

E-mail:dorota.kluk@inig.pl

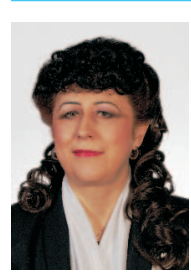

Prof. nzw. dr hab. inż. Teresa STELIGA

Kierownik Zakładu Technologii Eksploatacji Płynów Złożowych.

Instytut Nafty i Gazu - Państwowy Instytut Badawczy

ul. Lubicz 25 A

31-503 Kraków

E-mail:teresa.steliga@inig.pl 